\begin{tabular}{|c|c|c|c|c|c|c|}
\hline \multirow{4}{*}{ Impact Factor: } & ISRA (India) & $=3.117$ & SIS (USA) & $=0.912$ & ICV (Poland) & $=6.630$ \\
\hline & ISI (Dubai, UAE & $=0.829$ & РИНЦ (Russia) & $=0.156$ & PIF (India) & $=1.940$ \\
\hline & GIF (Australia) & $=0.564$ & ESJI (KZ) & $=8.716$ & IBI (India) & $=4.260$ \\
\hline & JIF & $=1.500$ & SJIF (Morocco) & $=5.667$ & OAJI (USA) & $=0.350$ \\
\hline
\end{tabular}

\section{SOI: $1.1 /$ TAS $\quad$ DOI: $10.15863 /$ TAS \\ International Scientific Journal Theoretical \& Applied Science}

\author{
p-ISSN: 2308-4944 (print) e-ISSN: 2409-0085 (online) \\ Year: $2019 \quad$ Issue: $07 \quad$ Volume: 75
}

Published: 29.07 .2019

http://T-Science.org
QR - Issue
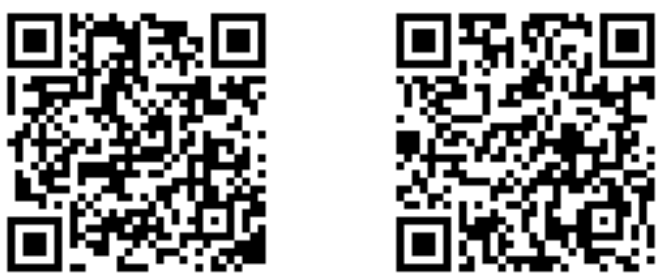

Alina A. Karahanova Kyrgyz National University name of Zhusup Balasagyn 3rd year graduate student of the Department of civil law

\title{
CONCLUSION OF MARRIAGE WITH PARTICIPATION OF FOREIGN PEOPLE IN THE KYRGYZ REPUBLIC
}

Abstract: The article discusses the issue of marriage with the participation of foreign citizens in the Kyrgyz Republic. The forms, procedure and conditions for entering into marriage with the participation of foreign citizens in the Kyrgyz Republic are described in detail.

Key words: marriage, a foreign citizen, the family.

Language: Russian

Citation: Karahanova, A. A. (2019). Conclusion of marriage with participation of foreign people in the Kyrgyz republic. ISJ Theoretical \& Applied Science, 07 (75), 332-335.

Soi: http://s-o-i.org/1.1/TAS-07-75-52 Doi: crossef https://dx.doi.org/10.15863/TAS.2019.07.75.52

Classifiers: Jurisprudence.

\section{ЗАКЛЮЧЕНИЕ БРАКА С УЧАСТИЕМ ИНОСТРАННЫХ ГРАЖДАН В КЫРГЫЗСКОЙ РЕСПУБЛИКЕ}

Аннотация: В статье рассматривается вопрос о заключении брака с участием иностранных граждан в Кыргызской Республике. Подробно изложены формы, порядок и условия заключения брака с участием иностранных граждан в Кыргызской Республике.

Ключевые слова: брак, иностранный гражданин, семья.

\section{Введение}

Вопросы правового регулирования семейных отношений с участием иностранных граждан и лиц без гражданства имеют особую актуальность всегда. Это связано с рядом причин объективного характера: распад советского союза и появление на его территории независимых государств; многократное усиление миграции населения, включая свободный выезд из Кыргызской Республики граждан Кыргызской Республики и въезд в Кыргызскую Республику иностранных граждан и лиц без гражданства; развитие деловых и личных контактов граждан с иностранными гражданами. Следствием перечисленных обстоятельств стал значительный рост числа браков кыргызских граждан с иностранными гражданами, увеличение случаев разного гражданства членов семьи, то есть возникают разнообразные семейные отношения с участием иностранного (международного) элемента (заключение брака, расторжение брака, признание брака недействительным, личные неимущественные и имущественные отношения между супругами, имущественные отношения между родителями и детьми и др.) [1, с. 621]. Распространенность семейных отношений, осложненных иностранным элементом, создало проблему разрешения противоречий между семейным законодательством Кыргызской Республики и других государств, граждане которых все чаще стали попадать в сферу действия кыргызского семейного права, что потребовало соответственно надежных гарантий их прав в семейных отношениях на территории Кыргызстана. С другой стороны, не менее важной являлась задача соблюдения законных прав и интересов и граждан Кыргызской Республики в семейных отношениях с участием иностранных граждан и лиц без гражданства, особенно детей (при усыновлении детей - граждан Кыргызской Республики иностранными гражданами и лицами без гражданства, регулировании алиментных 


\begin{tabular}{|c|c|c|c|c|c|c|}
\hline \multirow{4}{*}{ Impact Factor: } & ISRA (India) & $=3.117$ & SIS (USA) & $=0.912$ & ICV (Poland) & $=6.630$ \\
\hline & ISI (Dubai, UAI & $=0.829$ & РИНЦ (Russia & $=0.156$ & PIF (India) & $=1.940$ \\
\hline & GIF (Australia) & $=0.564$ & ESJI (KZ) & $=8.716$ & IBI (India) & $=4.260$ \\
\hline & JIF & $=1.500$ & SJIF (Morocce & $=5.667$ & OAJI (USA) & $=0.350$ \\
\hline
\end{tabular}

обязательств родителей и детей и т. п.). В этой связи назрела и необходимость принципиального изменения подхода к возможности применения норм иностранного семейного права в регулировании семейных отношений, поскольку существовавшее ранее отрицательное отношение к этому вопросу во многих случаях вело к ущемлению прав и интересов как отечественных, так и иностранных граждан. С принятием Семейного кодекса эти проблемы были в основном решены, и, кроме того, устранены пробелы, имевшие место в ранее действовавшем законодательстве.

B разделе VII Семейного кодекса Кыргызской Республики от 30 августа 2003 года № 201 "Применение семейного законодательства к семейным отношениям с участием иностранных лиц и лиц без гражданства" предусмотрены основания и условия применения семейного законодательства Кыргызской Республики и норм иностранного семейного права к семейным отношениям с участием иностранных лиц и лиц без гражданства, а также к семейным отношениям только кыргызских граждан, если эти отношения связаны с территорией иностранного государства [2, c. 622]. Необходимо отметить, что под гражданством следует понимать правовую принадлежность лица к конкретному государству, т.е. признание этого лица в качестве полноправного субъекта правовых отношений [3, c. 276]. Иностранными гражданами, о которых идет речь в разделе VII Семейного кодекса Кыргызской Республики, являются лица, не являющиеся гражданами Кыргызской Республики, принадлежность которых к гражданству другого государства подтверждается соответствующим документом (как правило, национальным паспортом). Конституция Кыргызской Республики допускает возможность приобретения гражданами Кыргызской Республики одновременно и гражданства иностранного государства (двойное гражданство) в соответствии с национальным законом или международным договором Кыргызской Республики. При таких обстоятельствах гражданин - обладатель двух гражданств формально обязан исполнять законодательство обоих государств, гражданство которых он имеет [4].

Закон Кыргызской Республики «О гражданстве Кыргызской Республики» от 21 мая 2007 года № 70 гласит о том, что наличие у гражданина Кыргызской Республики гражданства иностранного государства не умаляет его прав и свобод и не освобождает от обязанностей, вытекающих из кыргызского гражданства, если иное не предусмотрено законом или международным договором" [5].
В Семейном кодексе Кыргызской Республики не содержится специальной нормы о правовом статусе иностранных граждан и лиц без гражданства в Кыргызстане в брачно-семейных отношениях [6]. Это объясняется тем, что их правовое положение определено Конституцией Кыргызской Республики.

Согласно Конституции Кыргызской Республики иностранные граждане и лица без гражданства пользуются правами и несут обязанности наравне с гражданами Кыргызской Республики, кроме случаев, установленных национальными законами или международными договорами [7]. Действие Конституции Кыргызской Республики и национального законодательства распространяется не только на граждан Кыргызской Республики, но и на иностранных граждан и лиц без гражданства, находящихся на территории Кыргызской Республики, за отдельными исключениями, специально оговоренными законом, то есть для них установлен национальный режим независимо от места постоянного проживания.

В соответствии с Конституцией Кыргызской Республики иностранные граждане и лица без гражданства пользуются в Кыргызской Республике национальным режимом в семейных отношениях [7]. Они обладают такой же правоспособностью и дееспособностью в семейных отношениях, как и граждане Кыргызской Республики (то есть могут вступать в брак, расторгать брак, иметь родительские права и обязанности и т. п.), за некоторыми исключениями [8, с. 623]. Коллизионные нормы, регулирующие применение семейного законодательства $к$ отношениям с иностранным элементом, содержатся не только во внутреннем законодательстве. Коллизионные нормы содержатся в международных конвенциях, участницей которых является Кыргызская Республика. Говоря о правовом регулировании брака с участием иностранных граждан и лиц без гражданства, необходимо отметить, что в различные исторические периоды в Кыргызской Республике отношение к бракам кыргызов с иностранцами было неодинаковым, в том числе и негативным, что находило свое отражение и в семейном законодательстве. Во многом это было обусловлено религиозной формой заключения брака и предрассудками религиозного характера.

При заключении браков мусульман с людьми другого вероисповедания замечалось существенное ущемление прав и законных интересов лиц, не исповедовавших мусульманство. На протяжении длительного времени в истории кыргызов фактически не допускалось и применение норм иностранного семейного права. 


\begin{tabular}{|c|c|c|c|c|c|c|}
\hline \multirow{4}{*}{ Impact Factor: } & ISRA (India) & $=3.117$ & SIS (USA) & $=0.912$ & ICV (Poland) & $=6.630$ \\
\hline & ISI (Dubai, UAI & $=0.829$ & РИНЦ (Russia & $=0.156$ & PIF (India) & $=1.940$ \\
\hline & GIF (Australia) & $=0.564$ & ESJI (KZ) & $=8.716$ & IBI (India) & $=4.260$ \\
\hline & JIF & $=1.500$ & SJIF (Morocco & $=5.667$ & OAJI (USA) & $=0.350$ \\
\hline
\end{tabular}

Как показывает история советского периода, то согласно ст. 161 КоБС при заключении на территории советского союза браков советских граждан с иностранными гражданами и браков иностранных граждан между собой разрешалось использовать только советское семейное законодательство. Безусловно, это ущемляло права иностранных граждан и не могло не сказаться на динамике браков с их участием, которые в СССР были нераспространенным явлением.

Свобода выезда граждан за пределы Кыргызской Республики, а также свобода въезда (для граждан многих стран) в Кыргызскую Республику, привлечение на территорию Кыргызской Республики иностранных инвесторов и трудоустройство граждан Кыргызской Республики за границей существенно сказались на расширении контактов кыргызских граждан с иностранцами и, как следствие, на увеличении количества "интернациональных" браков. Закон не предусматривает каких-либо препятствий для граждан к вступлению в брак на территории Кыргызской Республики по национальному или расовому признаку. Способность лица к вступлению в брак определяется законодательством государства, гражданином которого данное лицо является. Вместе с тем при этом следует учитывать особенности национального законодательства государства, гражданином которого является лицо, вступающее в брак, предусматривающего иные, чем в Кыргызской Республике, условия вступления в брак, или даже не исключающего возможности многоженства (полигамии). В этой связи для защиты законных прав и интересов граждан Кыргызской Республики существенное значение имеют положения ст. 163 Семейного кодекса о форме, об условиях и порядке заключения браков с иностранными гражданами на территории Кыргызской Республики. В соответствии с п. 1 ст. 163 Семейного кодекса форма и порядок заключения брака на территории Кыргызской Республики определяются законодательством Кыргызской Республики. Отсюда следует, что на территории Кыргызской Республики брак во всех случаях должен заключаться в органах загса. Брак, совершенный по религиозным обрядам, а также фактические брачные отношения не порождают правовых последствий. Условия заключения брака на территории Кыргызской Республики определяются для каждого из лиц, вступающих в брак, законодательством государства, гражданином которого лицо является в момент заключения брака, с соблюдением требований статьи 15 Семейного кодекса в отношении обстоятельств, препятствующих заключению брака.

Такими обстоятельствами считаются:

1) лицами, из которых хотя бы одно лицо уже состоит в другом зарегистрированном браке;

2) близкими

родственниками (родственниками по прямой восходящей и нисходящей линии (родителями и детьми, дедушкой, бабушкой и внуками), полнородными и неполнородными (имеющими общих отца или мать) братьями и сестрами;

3) усыновителями и усыновленными;

4) лицами, из которых хотя бы одно лицо признано судом недееспособным вследствие психического расстройства.

Что касается заключения браков между иностранными гражданами на территории Кыргызской Республики в дипломатических представительствах и консульских учреждениях иностранных государств [4]. То в соответствии с ч.2 ст. 164 Семейного кодекса браки между иностранными гражданами, заключенные на территории Кыргызской Республики в дипломатических представительствах и консульских учреждениях иностранных государств, признаются на условиях взаимности действительными в Кыргызской Республике, если эти лица в момент заключения брака являлись гражданами иностранного государства, назначившего посла или консула в Кыргызской Республике.

\section{Заключение}

Таким образом, рассмотрев в данной статье вопрос о заключении брака с участием иностранных граждан можно отметить, что в Семейном Кодексе Кыргызской Республики предусмотрен целый раздел VII «Применение семейного законодательства к семейным отношениям с участием иностранных граждан и лиц без гражданства», в котором предусмотрены формы, порядок и условия заключения брака.

\section{References:}

1. Pchelintsev, L. M. (2002). Family Law of Russia. (p.621). Moscow: Norma.
2. Pchelintsev, L. M. (2002). Family Law of Russia. (p.622). Moscow: Norma. 


\begin{tabular}{|c|c|c|c|c|c|c|}
\hline \multirow{4}{*}{ Impact Factor: } & ISRA (India) & $=3.117$ & SIS (USA) & $=0.912$ & ICV (Poland) & $=6.630$ \\
\hline & ISI (Dubai, UAE & $=0.829$ & РИНЦ (Russia) & $=0.156$ & PIF (India) & $=1.940$ \\
\hline & GIF (Australia) & $=0.564$ & ESJI (KZ) & $=8.716$ & IBI (India) & $=4.260$ \\
\hline & JIF & $=1.500$ & SJIF (Morocco) & $=5.667$ & OAJI (USA) & $=0.350$ \\
\hline
\end{tabular}

3. Baglay, M. V. (2002). Constitutional law of the Russian Federation. (p.276). Moscow: Norma.

4. (2003). The Family Code of the Kyrgyz Republic of August 30, 2003 No. 201 [Electronic resource]. Retrieved May 17, 2019, from http://cbd.minjust.gov.kg/act/view/ruru/1327?cl=en-rucl=ru-ru

5. (2007). Law of the Kyrgyz Republic "On Citizenship of the Kyrgyz Republic" dated May 21, 2007 No. 70. [Electronic resource]. Retrieved May 15, 2019, from http://cbd.minjust.gov.kg/act/view/ru-ru/13499
6. (2003). The Family Code of the Kyrgyz Republic of August 30, 2003 No. 201 [Electronic resource]. Retrieved May 17, 2019, from http://cbd.minjust.gov.kg/act/view/ru$\underline{\mathrm{ru} / 1327 ? \mathrm{cl}=\mathrm{en}-\mathrm{rucl}=\mathrm{ru}-\mathrm{ru}}$

7. (2010). Constitution of the Kyrgyz Republic (Adopted by referendum (national vote) on June 27, 2010) [Electronic resource]. Retrieved May 15, 2019, from http://cbd.minjust.gov.kg/act/view/ru$\mathrm{ru} / 202913$ ?cl=ru-ru

8. Pchelintsev, L. M. (2002). Family Law of Russia. (p.623). Moscow: Norma. 